\title{
Selling Shares in CoOL
}

\author{
(Vendendo Ações com Calma)
}

Simon GIEve

(University of Leicester, School of Education)

\begin{abstract}
RESUMO: No contexto da globalização da produção de roupas esportivas e da pilhagem dos recursos culturais semióticos na moda da roupa esportiva, este artigo examina a linguagem dos elementos interpessoais de Relatórios Anuais de Empresas na indústria da moda esportiva norte-americana, particularmente a Carta aos Acionistas, em Relatórios Anuais recentes das empresas Hilfiger, Nike, Polo Ralph Lauren e Reebok. Nesses Relatórios, o gênero relatório financeiro vem sendo 'colonizado' pelo discurso mercadológico, e o potencial flexivel do gênero Relatório Anual é explorado para representar as empresas para acionistas (potenciais) numa combinação de discursos dos esportes, dos negócios e das finanças com os da globalização, da primazia e da americanização. Para essas empresas, a globalização se apresenta efetivamente como a expansão externa dos valores norte-americanos no mercado mundial.
\end{abstract}

KEY-WORDs: Company Annual Reports; Globalisation; Marketisation; Critical discourse analysis.

ABSTRACT: In the context of globalisation of production of sports apparel and the plundering of semiotic cultural resources in the design of fashionable sportswear, this paper examines the language of the interpersonal elements of Company Annual Reports in the US sports/fashion industry, in particular the Letter to Shareholders in recent Annual Reports from Hilfiger, Nike, Polo Ralph Lauren and Reebok. In these Reports, financial reporting is increasingly being colonised by marketing discourse, and the flexible potential of the Annual Report genre is being exploited to represent companies to (potential) shareholders in a compound of the discourses of sports, business, and finance with those of globalisation, primacy, and Americanism. Globalisation for these companies is effectively presented as the outward expansion of American values into the world market.

PaLAVRas-Chave: Relatórios Anuais de Empresas; Globalização; Mercadorização; Análise de discurso crítica. 


\section{Introduction}

In this paper I will explore how branded clothing and footwear companies represent themselves to investors in one of the principal avenues of corporate external communications available to them - the Annual Report. I became interested in the Annual Report after reading Klein's (2000) account of how substantial sectors of American industry no longer manufacture and sell products as 'things' so much as 'brands'. One of her prime examples is sports and casual clothing and footwear, which is not sold as 'a shoe', 'a T-shirt', or 'a pair of trousers' in the same way as in the old days of grocery stores that sold flour, dried fruit and grains out of barrels. No, we are now being sold Tommy Hilfiger jerseys, Nike shoes, Ralph Lauren shirts, Diesel jeans, and what we are buying is not so much a shoe as an image and an identity which has been packaged into a style. Klein was interested in the sources of the semiosis that is now being marketed by these corporations, and she found it in black youth urban sub-culture, predominantly hip-hop, that is exploited for its 'cool' style innovations and used as a test-bed for new products which are then sold back to consumers keen to keep abreast of cool fashion. Klein calls this the 'theft of cultural space'. Adidas, for example, marketed its Run-DMC shoes as "designed to be worn without laces" after rap band Run-DMC's 1986 hit 'My Adidas' referred to their habitual wearing of Adidas tracksuits and sneakers, and thousands of fans followed suit. T. What band members had adopted as their own fashion statement, taking the laces out of their Adidas to distance themselves from the shoe's corporate identity, was picked up by the company and sold back to fans as the new cool branded items. Tommy Hilfiger redesigned their sportswear line to appeal more to the hip-hop aesthetic with "bolder colors, bigger and baggier styles, more hoods and cords, and more prominence for logos and the Hilfiger name" (Smith 1977), and supplied rapper Snoop Dogg with free clothes when they found out that the 'white-preppy' image associated with Hilfiger was selling to inner-city black youth who took to the 'yacht club' image. There is also a certain amount of international semiotic plundering, as in Gap's Banana Republic brand, or Perry Ellis' PING and Cubavera. ${ }^{1}$ Yet these corporations do not market to their mainstream consumers using black

Klein cites Che Guevara's appearance in ads for Revolution Soda, Maoist references in Prada's 1998 collection, and Anna Sui's bikini tops 'inspired' by the Chinese occupation of Tibet. 
urban sub-cultural iconography; Tommy Hilfiger ads are comfortably middle class suburban images of carefree success, carefully racially balanced and all scrubbed clean. The question arises how these fashion-based corporations make use of their semiotic sources, whatever their origin, and whether they value them enough to feature them as part of their corporate cultural capital when addressing the people who provide them with the financial capital they also need - their investors. I will investigate here whether such brand-based corporations, which accrue profits by selling pre-fabricated cultural identities, include representations of cultural resources (espoused values, semiotic capital, cultural identifications) in their Annual Reports to investors, and what discursive strategies are mobilised by American fashion and sports businesses to deal with the interface between culture and economics.

In Smith's (1997) discussion of 'mass customization' in the garment industry he refers to the separation between capital concentration in the North and production in the South as enabling, and leading to, 'mass designer fashion'. Whilst the availability of cheap labour leads to the relocation of manufacturing overseas and domestic 'downsizing', competitive advantage at home is found in acceleration of sales through speeded-up product development and change, faster fashion cycles, lower inventories, and faster distribution times. It then becomes the responsibility of the overseas manufacturers to make sure that accelerated production turnaround time is achieved; most Hilfiger clothing is made in Hong Kong, Sri Lanka, Macao, Indonesia, and California. Mass-customisation is heavily dependent on information technology to manage the rapid distribution and turn-around cycles required on the one hand, and the other hand on close links with consumers both in the form of surveillance of their consumption patterns and in order to promote brand awareness. This has meant the enlistment of 'high-visibility consumers', or celebrity bodies' to promote clothes and shoes, particularly, in Hilfiger's case, AfricanAmerican rap musicians and sportsmen - part of the 'regulatory elite' in U.S. black culture. In order to make use of mass-produced clothing as cultural signifiers consumers of mass designer fashion, need to be able to purchase identifiable and unique products with readily identifiable logos in a house style, yet with appreciably different 'looks' from season to season, year to year, and a wide range of product choices (: 252). Tommy Hilfiger led the way in developing mass customisation which could deliver these products in the 1990s, with spectacular financial rewards accruing to 
investors ${ }^{2}$. Smith sees the use of the American patriot theme and flag motif by Hilfiger as symptomatic of the relationship between the international regulation of labour on the one hand, and the production of regulated sub-cultural identities at home on the other:

The display of the U.S. flag and the appeal to American identity obscure both the international and the subnational processes that are at stake in the political-economic and cultural formations of this new world order. Another way of putting this is to say that the U.S. national motif precisely names the power which resides over the division between the zoned labour of the South and the massified consumption in the North and confirms that division as an opposition of interests. (op cit p.261-2)

A cursory reading of the Annual Reports of such companies as Ralph Lauren, Perry Ellis, Gap, Hilfiger, Nike, Reebok, and Levi Strauss reveals that they do not promote the advantages of a cheap globalised labour force when trying to impress investors. It may be seen as a poor strategy, considering the amount criticism that has been attracted (see Ross 1997, for example). They do stress a rather more abstract version of what it means to be a global business however, with a stress on more internationalised consumer markets. Before looking at how investors are addressed in a small sample of Annual Reports, I will briefly consider the nature of the genre, and how a document originally intended as a vehicle for financial reporting has been colonised by marketing discourse. I will not devote any space to discussing the models of genre and discourse that I follow on; suffice it to say that van Leeuwen (1993) and Fairclough (1992, 1995a, 1995b) cover the ground.

\section{The Genre of the Annual Report}

Company Annual Reports are hybrid texts with multiple purposes. They are primarily addressed to investors, who 'require information about the performance and the prospects of the entity and about the stewardship of the board of directors whom they have appointed to the entity'

2 Smith noted a $80 \%$ rate of gross profits ( $\$ 58 \mathrm{~m}$ ) in 1996, with the original late 1980s investors cashing in on $\$ 50 \mathrm{~m}$ worth of their stock in 1995 , after a $106 \%$ year-on increase in stock value. Hilfiger himself stayed on with a $\$ 6 \mathrm{~m}$ a year salary after pocketing his share. 
(McMonnies 1988:19). As well as equity investors and loan creditors, various other groups also require information about companies: employees, analyst-advisors, business contacts, and government (McMonnies 1988:27). This information consists of the corporate objectives of the entity and how far performance reaches those objectives, the total wealth of the entity, its future plans, the economic environment in which it operates, its ownership and management control (:29). On the basis of this information investors will make judgements about whether to buy, sell or maintain shares, or otherwise intervene in the management of the enterprise. In reality, published financial accounts are often arcane and not accessible to ordinary investors, and companies frequently have an interest in keeping knowledge about corporate financial performance to themselves. Management frequently stand to gain by not revealing accurate company information, and they may even enlist the cooperation of their official auditors, who have to publicly ratify the accuracy of the report, in their deception, as in the case of Enron and Arthur Andersen (http://www.thedailyenron.com). In economic discourse, this flow of company information is required in order to promote market efficiency in share dealing.

Nevertheless, the Annual Report does seek to satisfy existing shareholders through the presentation of information. They have to be made accessible to small private shareholders, to institutional investors, and to market analysts who advise others on share dealings. They are provided to all shareholders annually, but they are also public documents available on demand to potential investors, and are now frequently made available in downloadable form on company websites ${ }^{3}$. There are also legal financial reporting requirements to be satisfied. Thus they have to address both novice and expert readers. At the same time they have to show that the company is performing well, and that the directors are aware of market trends and problems which need to be addressed, and that they have a strategy to deal with them. They have to demonstrate that the future of the company is secure and profitable to maintain existing investors and attract new ones. Some investors may be persuaded by the nature of the product itself, but others may find confidence in the person of the Chief Executive Officer or Board members, or in company values, or its marketing strategy, or in financial figures alone. The Annual Report also seeks to

\footnotetext{
Some websites have also been created to help direct investors to online company reports (www.reportgallery.com; www.zpub.com/sf/arl )
} 
attract new investors, and some companies have begun to exploit their potential as advertisements, not for the company's products but for the company itself. All these potential readers have to be addressed.

Annual reports form historical chains, with new versions published every year that necessarily have to be related to previous editions, demonstrating the continuity of the company and a sense of company history, as some investors may consider themselves loyal to certain brands or company values, and market analysts will be keenly aware of any attempts to rewrite company history.

The Reports are usually multi-authored, with a personalised contribution from the Chairman of the Board or Chief Executive Officer, a report from the marketing director and the chief financial officer, an independent accountant's report, and other contributions from various sources within the company. Yet they are presented as single documents according to a coherently designed corporate image, so public relations departments are heavily involved. The casual reader picking up these documents will notice how much design effort has gone into their production to create visual and thematic coherence out of what was once simply a financial report. The Annual Reports Library which also provides a consultation service for writing company reports (www.zpub.com/sf/arl) refers to Annual Reports as a "corporate "work of art" and recommends that report writers "Tell a story, Keep it simple, Make it readable." The use of narrative as a discourse strategy in Annual Reports will be discussed below.

Whilst the Annual Report is not the sole basis on which investors base their decisions, and may not even be referred to at all, it is nevertheless one of the few places apart from press briefings and paid advertisements (which often now sell the company brand itself as much as any of its individual products) where the company presents itself to investors in order to maintain its essential supply of capital, as well as to its employees, to the public, its network of business contacts, and to government. The Annual Reports Library suggests that "reviewing a company yearly is the minimum diligence required" for investors. A badly-produced report would effect a company's credibility and the confidence of potential investors, whilst an inaccurate report would have serious consequences.

Nine elements in the schematic structure of annual reports are identified by the Annual Reports Library, which suggests that 4-9 are 
obligatory stages, and that while 1-3 and 9 are better located near the beginning, 4 must precede 6,5 should be either before or after 6 , and 7 and 8 should be placed in the last few pages:

1. Chairman of the Board Letter (a 1-2 page overview covering developments, goals achieved or missed, actions taken and industry conditions)

2. Sales and Marketing (what and where the company sells and makes its money)

3. 10 Year summary of financial figures

4. Management discussion and analysis of significant trends over past two years

5. Auditors' opinion letter

6. Financial Statements

7. Subsidiaries, Brands and Addresses

8. List of Directors and Officers

9. Stock Price

\subsection{The colonisation of financial reporting by marketing discourse}

Let us compare this generalised schematic structure with an actual example. Annual Reports in a wide variety of fields are now being colonised by discourses other than those of accountancy, finance and marketing, in what IBM calls the 'editorial' section ${ }^{4}$. So too, they are drawing on a wider range of genres than financial statements and business reports. Reference has already been made to the contribution of design departments in the construction of Annual Reports: what is being designed is something much more akin to an advertising feature than a business report. This may take a fairly simple form, as in the Gap 2002 report which includes six pages of full-colour fashion photographs between the Letter to Shareholders and the 3-year financial highlights. I will take the adidas-Salomon 2001 report as a more sophisticated example, working from the website version ${ }^{5}$.

\footnotetext{
4 Consider recent Annual Reports from IBM, Nokia, Aventis, or Monsanto, for examples.

5 http://www.adidas-salomon.com/en/investor/_downloads/pdf/annual_reports/2001/ AR_englisch2001_e.pdf
} 
The Report does not have a title as such (titles such as Nokia's 1999 'No Limits', for example, immediately introduce a narrative element), but the front cover colour photo of a football stretching out the back of a net with the Adidas logo clearly visible, the end result of a high-velocity shot at goal, signifies a success story. The table below outlines the contents of the report, and shows how complex the structure is. It is knitted together through the use of non-textual cohesion strategies: a strong integrated graphical design theme, three sections with 'Line' titles, the use of photographs in two styles: sports performance and 'family snapshot'.

\begin{tabular}{|c|c|c|}
\hline $\begin{array}{l}\text { Number } \\
\text { of Pages }\end{array}$ & Contents & Comments \\
\hline 1 & Colour Photograph & Title page \\
\hline 3 & Financial highlights & $\begin{array}{l}\text { Strong graphic design, featuring two-colour } \\
\text { theme, including 'Evidence of Top Performance' }\end{array}$ \\
\hline 1 & $\begin{array}{l}\text { Corporate Mission } \\
\text { Statement }\end{array}$ & Discourse of values \\
\hline 1 & 'Crossing the Line' & Title page to 37 page section on 'Strategy' \\
\hline 1 & Colour Photograph & $\begin{array}{l}\text { Two Ethiopian runners crossing finishing line in } \\
\text { Adidas sponsored race }\end{array}$ \\
\hline 1 & Executive Board photos & $\begin{array}{l}\text { Five snapshots of Board members engaged in } \\
\text { sporting activities }\end{array}$ \\
\hline 3 & CEO Letter to Shareholders & $\begin{array}{l}\text { Off-set slanted layout, headed by snapshot of } \\
\text { CEO shooting at goal }\end{array}$ \\
\hline 2 & The Share & $\begin{array}{l}\text { Presentation of recent share performance with } \\
\text { strong design features: financial discourse }\end{array}$ \\
\hline 24 & Brand strategies & $\begin{array}{l}\text { Marketing discourse, with same snap-shot } \\
\text { graphics in integrated design style }\end{array}$ \\
\hline 2 & Global Operations & Marketing strategy \\
\hline 2 & $\begin{array}{l}\text { Social and Environmental } \\
\text { Affairs }\end{array}$ & 'Corporate responsibility' \\
\hline \multirow[t]{2}{*}{2} & Employees & Personnel policy, with thanks to workers. \\
\hline & 'On the Line' & $\begin{array}{l}\text { Title page to } 27 \text { page section on 'Management } \\
\text { Discussion and Analysis' }\end{array}$ \\
\hline 1 & Colour Photograph & Sports official pointing at a line on a track \\
\hline 24 & Management reports & Integrated style in graphics design \\
\hline 2 & Board & List of Board members \\
\hline 1 & 'Between the Lines' & Title page to \\
\hline 1 & Colour photograph & Sports official changing score-board figures \\
\hline 53 & Financial reports & $\begin{array}{l}\text { Including Consolidated Financial Statements, } \\
\text { 'Notes', Auditor's report, Four-year overview }\end{array}$ \\
\hline
\end{tabular}


This is clearly selling the brand, not just describing the strategies used to market the brand. Features such as the Mission Statement, Social and Environmental Affairs, Employee policy statement, and personalisation of the management team with sporty family snaps are not required of a financial reporting vehicle; they are clearly designed to market the company itself. Just as one example of how the text itself makes use of marketing discourse, there follows a short extract from page 15, the title page of the 'Brand Strategies' section:

Forever Sport is the largest adidas division with products "engineered to perform" for athletes of all abilities. Technological innovation and a commitment to performance are the cornerstones of this division. The Original division is the fastest-growing adidas division. Originals products seek to extend the unique and authentic heritage of adidas to the lifestyle market.

The adidas-Salomon report is merely an example of a trend that is widespread. What was primarily intended to be a source of information to investors and others is now being colonised by marketing discourse. Some companies now even publish the financial data itself bound separately from the other sections, which allows them to satisfy reporting requirements but to reach non-expert readers through a completely difficult route: an aesthetic appeal, and an appeal to solidarity with company values and identity. The separation of the financial statement into a separately bound booklet addresses the difficulty of retaining coherence in a text which is trying to go in two different directions. The legal requirement for financial reporting, and the financial detail required by some investors, does not now get in the way of the selling of the company as a character with an individual identity.

\section{The Letter to Shareholders}

There is a large amount of flexibility in the Annual Report genre in terms of what elements can be included, and the styles of language and presentation used. They can be fairly business-like, sticking closely to the marketing and financial reports that would be produced for internal consumption and industry insiders. But they also draw on features of advertising, with the freedom to use twenty or more pages for free, instead of the one-page or two-page format to which they are restricted in magazine 
or newspaper outlets. Yet they cannot be too advertisement-like, as most readers will not be persuaded to buy or keep stocks by eye-catching design and marketing rhetoric. Most investors will be more concerned with judging the company's representation of itself according to economic criteria - its past performance and its future stability, growth potential and profitability. They will evaluate these to a certain extent, however, by the professionalism shown in the presentation of the annual report, the reputation and personal qualities of its directors, the company's business sense in terms of the quality of awareness it shows in assessing market trends, and its strategy for the future as well past performance. Part of investors' evaluation therefore will be on the basis of impression, and will be susceptible to 'impression management' or 'spin', and part will rely on sincerity judgements, and these two factors will be in tension with each other. If readers are confident of the sincerity of the report, their evaluation of the truth value of the report will be enhanced. If readers doubt the sincerity of the writer they will feel that they are being manipulated or being 'spun a line', and may evaluate the truth value of the report more negatively (Habermas, 1984). Financial reporting itself is usually assumed to be sincere (perhaps less so than before the Enron scandal), since it is conducted by professional accountants and endorsed by professional auditors. It is at the 'soft' end of company reporting, such as expressions of company values, corporate social responsibility, and mission statements that sincerity judgements are likely to be made.

We have noted that when it comes to fashion / sports wear, companies are effectively selling not products - the material goods themselves, the shirts and shoes and sports jackets - but a brand. It is a matter for research into reader response to establish the extent to which readers of annual reports allow judgements of brand strength or 'integrity' to influence their decisions, as opposed to financial performance. All we can say here is that confidence in such companies will be based to some extent on the images of the brands they market, and the increasing importance of branding would explain the presence of marketing discourse into Company Annual Reports, selling the company as a brand as much as its products. In investigating how far the necessity to create, protect and enhance brand image intrudes into investor communications in the Annual Reports of sports / fashion companies I will look at the Chief Executive Officer's letter to shareholders in the Annual Reports of four American businesses. I have chosen these texts partly because they are comparatively short, but mainly because of their interpersonal role. The CEO's Letter functions as a kind of 
motivational speech, having some resemblance to addresses made by luminaries or celebrities on such occasions as graduations, conferences, institutional dinners, Forwards to books or prefatory remarks by sponsors or patrons in other publications. As such it need not necessarily be connected to the main business of the speech event or document, but it lends authority and confers the approval of the powerful. It confirms that this person has read and approves of the document, and it also offers a link, however tenuous, between the most powerful figure in the company and the ordinary shareholder. It is therefore an aspect of tenor rather than field - it has a strongly phatic meaning ('the CEO is spending his time addressing you') - rather than ideational. It also has a thematic function, foregrounding certain aspects of what follows, and drawing intertextually from other parts of the document not written by the CEO. It will most likely be written afterwards, when the Report has been already read by the CEO, and will be a means of establishing the 'story' of the report. I realise the limitations of focusing on a short section of rather large texts, however, and the significant of the Letters to Shareholders must be seen in the context of the larger texts of which they form a small part.

\subsection{Tommy Hiffiger Corporation}

The Tommy Hilfiger Annual Report opens with a page of five-year summary financial statistics, showing a halting in the decline in net revenue, net income and earning per share recorded in the previous two years. This is followed by 'A Message from Tommy', a page of text which is unsigned, but topped with a head and shoulders shot of a relaxed, elegant and smiling Tommy Hilfiger, and finished at the bottom with the Hilfiger logo. It consists of 18 lines of centre-spaced bolded text in 8 paragraphs. It constructs a three-way identification between the Company as a legal and financial entity, America as a people a way of life and a set of values, and the product - clothing designs. To the extent that American business is also looking overseas for the capital required to sustain it, and equity investment from overseas has become more difficult to attract ${ }^{6}$, this is

\footnotetext{
6 "Foreign direct investment (spending on physical assets) in the US has dropped to $\$ 55 \mathrm{bn}$ (£38bn), down sharply from a peak of $\$ 155$ bn in mid-1999. Meanwhile FDI outflows from the eurozone have been cut in half to 91 bn euros in the past year. Equity flows (money spent on shares)
} 
perhaps a risky strategy, but Hilfiger is clearly not concerned by the possibility of alienating non-American investors. Indeed, Hilfiger, along with other corporations competing for capital in an international marketplace, may well be confident that the big institutional investors will not be swayed by public-relations messages at all, but base their decisions solely on financial data and business prospects. Why then, are the 'extras' included in Annual Reports at all? Is it just the company speaking to itself and its employees?

Believing in and celebrating the American spirit!

That's what our company stands for. That's what we strive to achieve in our clothing, every day, for people everywhere.

So on September 11, we mourned a tragedy that struck America in many ways

Thousands of people lost their lives, many more lost friends and loved ones, and millions of lives were altered. For us at Tommy Hilfiger Corporation, with approximately 740 employees work in our New York City offices and 420 more in nearby New Jersey, the tragedy affected us deeply.

The attacks targeted symbols of America and the American way of life - values that, as a company, we have always celebrated

with our designs, styling and attitude. The ideals of freedom, individuality, opportunity, diversity and youthfulness, so much part of the American dream, are part of our corporate culture, and will always be so.

We would like to recognize the tremendous outpouring of support shown by our employees in the aftermath of that terrible day.

We would like to honor the courageous men and women who lost their lives trying to save the lives of others.

And we would like to honor the shining strength of the American spirit.

to the US have also tapered off by $40 \%$ to $\$ 115 \mathrm{bn}$, while equity flows to the eurozone have accelerated sharply to $251 \mathrm{bn}$ euros over the last year, from just $34 \mathrm{bn}$ euros." The Guardian, Feb 25th 2002. 
In this short text welour/us appears a total of 11 times. It is quite ambiguous who is included as welour/us; as a message from the founder of the company to shareholders it may be considered as a kind of 'royal' we, in which the principle of corporate leadership is represented by the voice of its figurehead. In that the company is owned by its shareholders, it could be taken to include the readers ('our Company'). It could also refer to the Company as in independent legal entity ('as a Company, we'), or to the directors ('we recognise the support shown by our employees'), or to the entire staff ('our corporate culture'). Hilfiger employees are most closely identified as New York and New Jersey office workers, rather than those engaged in the manufacturing process itself. In abstaining from making a clear claim about what or who constitutes 'Tommy Hilfiger', the text forces readers to decide for themselves how far the inclusiveness of 'we' extends. Insofar as Hilfiger strongly associates itself with 'high-visibility consumers', readers may also factor in these figures when establishing their own mental models of what the 'we-ness' of Hilfiger amounts to.

Whatever 'we' may be, it is here strongly associated with Americanness. On each of the eight occasions that the word America(n) appears, the words we / us / (our) company / our corporate culture appear in the same sentence. Geographical proximity is claimed between Hilfiger offices and staff and the New York City buildings which were destroyed on September 11th 2001; the emotions of those personally affected were apparently shared by the Corporation and its new York staff; and the attack on the World Trade Centre was an attack on American values that are also Hilfiger values: freedom, individuality, opportunity, diversity, and youthfulness, and these values are given material expression, in this text, in Hilfiger clothing designs. The World Trade Centre is identified as a symbol of America and the American way of life: the non-American companies and non-American people occupying it on September 11th are enrolled as honorary participants in the American way of life - it is not 'America' participating in international business, it is international business participating in 'America'.

The 'Message from Tommy' is followed by a two-page letter to shareholders from the co-chairmen of the board of directors. It is headed by a three-quarter length formal photograph, addressed 'Dear Shareholders', and signed at the bottom. It is a self-contained formal letter embedded within the Report. The representation of the company as 'we' is here complemented by a more personalised sense of 'we' as the Co- 
Chairmen themselves, who thank their employees and shareholders. The content is a summary of the company's performance over the past year and strategy for the year ahead, couched in financial and marketing discourse, and concludes with an appeal to shareholders not as investors who play the stock market for purely financial gain, but as 'loyal supporters'. What is considered important to assure shareholders positioned in this manner of is long-term stability and growth, confidence, strength, potential, and progress:

To our shareholders, we thank you for your loyal support as we continue to strive to enhance the long-term value of your investment. We are confident that we have the right strategy in place to leverage the enduring strength of the Tommy Hilfiger brand and to capitalise on the great potential of our increasingly global franchise. We look forward to keeping you apprised of our progress.

Let us examine the way in which the Company, America and the rest of the world are articulated in this letter. The company is identified as 'one of the world's pre-eminent lifestyle brands', which has a 'global brand presence' (mentioned twice) and an 'increasingly global franchise'. Specific mention is made of the acquisition of Tommy Hilfiger Europe (an 'exciting growth vehicle'), but no other international locations are mentioned. International growth is seen as the answer to the 'very challenging business conditions facing apparel manufacturers and retailers in the U.S.' . Yet, while it is not just an American but a global company in business terms, in terms of design values it relies on 'the enduring strength of our all-American style':

The Tommy Hilfiger name continues to stand for fashion-right, updated American "classics with a twist" that provide great value and appeal to a wide range of ages, demographics and lifestyles.

There is no sense here, however, of any need to localise the brand; it is not just Hilfiger clothing that is being sold world-wide, it is American style which, if we are to believe the Message from Tommy, reflect American ideals (freedom, individuality, opportunity, diversity and youthfulness).

This letter is followed by a four-page 'Letter from our Chief Executive Officer and President', again headed by a formal photograph, addressed 'Dear Shareholders', and signed 'Sincerely'. This comprises a longer version of the marketing and financial strategy already outlined. Early on, in the 
third sentence, we find the achievement of reconciling the contradictions between the company as a stable, enduring enterprise competing in a volatile fashion industry which requires constant adaptation, an American but also an expanding global business:

We are committed to remaining true to our heritage as a leading designer of updated American classics and are keenly focused on projecting our brand image of fun, youth and diversity in the global marketplace.

The single noun phrase updated American classics, which we also found in the letter from the Co-Chairmen, is doing a great deal of work here, proposing that there is such a thing as an American style, that it has a noble enduring ancestry, and that it faces the future. Hilfiger is one of the creators of this American style. The identification of American values, American clothing and Hilfiger, found in the 'Letter from Tommy' is somewhat toned down here to allow for a more inclusive interpretation of the brand image - there is nothing essentially American about fun and youth, although we perhaps recognise something peculiarly American in the focus on diversity. Diversity does not extend to the Hilfiger range however: it is the homogenous notion of updated American classics which is being sold to the world. As in the Co-Chairmen's Letter, the 'global appeal of the Tommy Hilfiger brand' seems to rely heavily on European success, and no other international locations are mentioned.

\subsection{Ralph Lauren}

Ralph Lauren's signed two-page 'Letter to Shareholders' as Chairman and CEO in the 2002 Ralph Lauren Annual report draws on the same discursive strategies found in the Tommy Hilfiger Annual Report, in that the essentially American qualities of the company are presented as having global reach:

- our global brand... expanded into 65 countries ... building a stronger global company ... $\$ 10$ billion in global retail sales ...the intelligent management of our increasingly global business

- an industry leader with worldwide presence ... we have grown the world of Polo Ralph Lauren ... we've grown our brand into an aspirational world of style 
- Polo Ralph Lauren understands what people want, both in America and abroad

- the finest specialty and department stores, both domestic and international

- we've been able to bring our vision of the best of America to people around the world

- While our business focus is global, our spirit remains truly American

- This year we celebrate 35 years of the American spirit of Polo Ralph Lauren

- In Milan ...we made American luxury synonymous with Polo Ralph Lauren

The American spirit is important to Polo Ralph Lauren, but it is never made clear exactly what that entails. 'Our creative spirit' is characterised as 'to do things right', but Polo Ralph Lauren's American spirit is rather vaguer. We are told that it was in evidence in their Olympic Games commercials, however, and people told Lauren 'how the images in the commercials spoke to them about America as they dream it to be'. But

Being a part of the American spirit is more than our approach to our business; it is an essential part of our identity and our longstanding commitment to the communities where we live, work and do business.

This spirit was invaluable after the attacks on September 11, 2001... I appreciate the way in which our people supported each other and assisted our friends and neighbours in need.

It seems strange to be a part of the American spirit, rather than to have the American spirit. It sounds like a mystical blending with the American animus, but it may amount to nothing more than what the British call 'the spirit of the blitz' - a coming together in mutual aid in times of crisis, in our case in British cities during the Nazi bombings of the second world war. Their approach to their business is to "do things right", a slogan repeated in the closing paragraph, which is to aim at the luxury end if the market. The 'longstanding commitment to communities' refers to the corporation's tax deductible public service fund, which has an emphasis on cancer care as well as the Start Spangled Banner restoration, 'a part of the "Save America's Treasures" campaign. The American spirit seems to be purely about being patriotic, therefore, and no particular values are associated with it, as in the case of Tommy Hilfiger. 


\subsection{Nike}

The Nike 2002 Annual Report is divided into five sections which are given equal status on the front cover?

\begin{tabular}{l|l}
\hline Chairman's Letter to Shareholders & 2 pages \\
\hline Presidents' Message: Year in Review & 2 pages \\
\hline 30 Years of Nike Moments & $\begin{array}{l}10 \text { pages, with colour photographs and } \\
\text { innovative design format }\end{array}$ \\
\hline $200210 K$ E Proxy & 103 pages: \\
& 2 pages of formal certification of the accuracy \\
& of the Report by the CEO and Chief finance \\
& Officer \\
& 63 pages of the actual financial document (form \\
& $10-$ K under the 1934 Securities Exchange act), \\
& 38 pages of Proxy voting documentation for the \\
& annual shareholders' meeting \\
\hline Corporate Information & 8 pages: names and addresses of officers and \\
& subsidiaries \\
\hline
\end{tabular}

Section 3 is essentially an advertising feature in the form of a celebration of 30 events during the course of the company history which are presented as turning points in the growth of the business or key moments illustrative of the company's putative ethos, and is superfluous to the annual report as a business reporting document. They include such 'Nike Moments' as when an employee on holiday watching the 1999 Tour de France being won by a Nike sponsored cyclist had the idea of having a matching yellow jersey made for the winner's baby son; they were duly photographed together on the winner's podium, in what was taken to be a marketing success story for Nike, and a symbol of Nike employees' dedication to their work.

In Nike's case, the Letter to Shareholders from the Chairman of the Board and CEO, Philip Knight (see Appendix), is a remarkable mix of memo, motivational speech, advertisement, and business report genres, in the discourses of sports, finance, and management. It is a celebration of the company's success rather than a progress report. Although the text is

I am working from the website edition found at http://www.nike.com/nikebiz/invest/reports/ ar $02 /$ index.html 
headed 'Chairman's Letter' it is in fact addressed 'To Our Shareholders', and there is no valediction (Yours truly etc.), simply Philip Knight's signature and job title. It contains no reference to the reader or the reader's situation, and is thus more like a company memo than a letter. It draws intertextually on discourses of sport and globalisation from other parts of the document, with only touches of financial discourse. The ' 30 years of Nike Moments' section of the report is heavily thematised however, with four references to 'Nike moments', foregrounded by separations from the body of the text in the form of hiatus marks (' ...a Nike moment...'). The particular success of the football division is also highlighted, with references to the success of the Brazilian team and large sales of football boots in Europe and jerseys in Korea, which are both mentioned in the following President's 'Year in Review' Message. It is not possible to say which was written before the other, but the repetition cannot be coincidental. Finally, much is made of the global nature of Nike's business, which can be seen as a 'spin' put on the financial data report for the benefit of readers aware of the popularity of contemporary globalisation discourses, a way of turning financial data into a story.

In terms of the functions of language it fulfils and text type(s) it constitute(s) letter represents a bit of a puzzle, however. In Longacre's terms it consists of narration and exposition. Using Jakobson's terms, there is some referential discourse, but we can discern also elements of poetic discourse (that wave of yellow sweeping across the great green lawn) and emotive discourse (I love being a part of this business'), and we have already referred to the phatic function, insofar as the CEO is sending a 'personal' message to each shareholder. Perhaps the most significant point to be made about such prefatory epistles, which are found at the front of many kinds of institutional reports, is that their purpose is indeed purely formal and it is not anticipated that many people will actually read them. This gives the writer a certain amount of license, however, which has been fully taken advantage of in the Hilfiger and Nike Letters, while in other cases they are much closer to summaries and interpretations of evidence presented in the main body of the Annual Report. This is not a disadvantage for discourse analysis, however. The more significant parts of the Report are more carefully constructed, more controlled, more formalised, and thus less interesting for me, if not for shareholders. In the Letter to Shareholders, the writer is more off-guard, more intertextually adventurous, and I suggest perhaps more revealing of company values and attitudes if we study the 
strategies through which such an 'inconsequential' text is knocked together and what work is required of readers to make it coherent. In the end we must accept that the primary function of the Letter is to induce, sustain and increase readers' confidence in the company as a safe place to invest their money. As such it is clearly connative (in Jakobson's terms), or hortatory (in Longacre's), although there is not a single instantiation of hortatory language, such as imperative verb forms. There is some argumentation present in a passage on the nature of global business, which is oriented towards establishing that Nike is not in fact a global company yet - which is not a argument for investing in it.

For critical discourse analysis the puzzle of generic form dissolves, however. The Letter demonstrates what Fairclough (1995:86) refers to as polyphonic generic heterogeneity. It does not unfold in stages as in the traditional schematic understanding of genre (Swales), as the Annual Report itself does. Nor is it ordered purely sequentially, with alternating clusters of clauses serving different purposes (van Leeuwen 1987), although there are is certainly iterative variation between narration and exposition. It's most notable feature, however, is variation within paragraphs and sentences.

It exhibits significant features of spoken mode, mixed in amongst more clearly written mode, and is in this respect the most significant example of the conversationalisation of institutional discourse (Fairclough 1995:130) in the corpus. For one thing, it is heavily personalised, though the use of 'I / my' (Philip Knight) as well as 'we / our' (Nike):

I can picture them all / I have used this space before to discuss our evolutionary tale / I love being a part of it / I'll tell you one thing that's truly global by almost any definition /

I consider every day of the past 30 years as preparation for this moment

It features direct address (I'll tell you one thing that's truly global) and rhetorical questions to readers (Why does it matter? / Could he be right?); non-finite clauses (I can picture them still. That wave of yellow sweeping across the great, green lawn called a pitch); short sentences (It was poetry.) and one-sentence paragraphs (The World Cup mattered in other ways, too.); and sentence-initial conjunctions (We love a good fight. And we're packing for Berlin. / But Nike refuses to be defined by where 
we once stood). The Letter is very much like a speech, then, in terms of its linguistic realisations. I previously referred to it as a 'celebration', in the style of a motivational speech intended to increase the commitment and allegiance of the audience, thus constituting adhortation. There are elements of exposition, particularly in the passages about globalised business and the global nature of sports in the second half of the text, and some references to financial data, but the reporting function is mostly left to other parts of the Annual Report. The predominant mode of the first half of the text, however, is narrative. A story is constructed of Nike's company trajectory over the past year and over the past thirty years. This is marked by the frequent use of sentence-initial adverbials both of time and place (which also contribute to the spoken style):

As the world stood witness ... / In leading retail shops across Europe / Eight months later... /

Then came September $11^{\text {th }} \ldots /$ For eight years $\ldots /$ This year, for the first time in our history ...

as well as more written-mode examples of narrative progression:

We entered FY'02 with ... / We decided to cross the threshold.../ Once .... now ... /

We have for years said that ... / We have come a long way from the days ...

The final sentence of the letter, picked out and reproduced in bold font in quotation marks in the margin under the 'Chairman's Letter' heading, encapsulates the notion of trajectory designed to make shareholders feel part of a historical endeavour:

I consider every day of the past 30 years as preparation for this moment ... this Nike moment $\ldots$ and all that follows.

Historical progression is emphasised even more strongly in the final paragraph itself in the three sentences which precede this:

Nike is 30 years old this summer. We have come a long way from the days of selling shoes out of the trunk of my car. But Nike refuses to be defined by where we once stood. I consider every day of the past 30 years as preparation for this moment ... this Nike moment ... and all that follows. 
The legal and business requirement for a company to report publicly on its 'total wealth and upon changes in that wealth during the past and expected in the future' (McMonnies 1988:17), so that investors can assess whether or not their money is in safe hands, is here inflected with a mythologizing appeal to the values of individualism and heroic success. Nike refuses to be defined as an entity by others, even by its own past.

In the terms of narrative analysis (Eggins and Slade 1997) the point of the narrative, the evaluation, is that, like Brazil, Nike as a company is a winner. This apparently is where it ends, and for investors this is taken to be sufficient. There is no explicit argumentative point being made (since Nike is a winner, and as an investor you will make money out of a winner, then (continue to) invest in Nike). In 'telling a story' company values are assumed to be shared, and the idea of a company with a history and a stable identity with which investors can identify is fostered. The drama of the narrative and the true demonstration of the hero's (Nike) worth is not just found in historical movement, however. There is a real sense here of obstacles overcome: Brazil was the underdog but came back to win the soccer World Cup, Nike 'entered FY '02 1\% down in futures orders' - and then came September $11^{\text {th }}$ - but eight months later 'delivered a $14 \%$ increase in earnings'. Brazil recaptured the World Cup, Nike sold 150,000 team jerseys to fans in Korea. In the same way, while Nike is still 'number two in the world's biggest sport, football', it will surely succeed in being number one. The implication is clear: the company that overcomes obstacles is a financially sound company and a safe place to invest your personal savings.

The intrusion of conversational (life-world) discourse into a business report is also apparent in the use of colloquialisms and informal lexis. In the following extract the shifts between financial discourse and life-world informal narrative with strong literary pretensions, ending with an advertising slogan, is remarkable:

We entered FY ' 02 with a $1 \%$ decline in futures orders, We had our work cut out for us. Then came September 11, and with it a bow wave of uncertainty. Restaurants, stadiums, theme parks, malls, all thinner of crowd, showed the wan face of anxiety. (...) We decided to cross the threshold of September $11^{\text {th }}$. Eight months later we delivered a $14 \%$ increase in earnings, and beat the S\&P by 45 points ( $+31 \%$ vs. $14 \%)$... a defining moment... a Nike moment 
Of note here also is the enrolment of sport into the field of business, where the crowds attending sporting events (and seeing Nike-sponsored teams and individual $s$ winning) share the same essential characteristics as shoppers, consumers of entertainment, and other parts of the service sector. This is not surprising for a company whose business is selling sports ware, of course, but significant work is done in the subsuming of other connotative meanings around the idea of sport to the business field. Sport as romance (That wave of yellow sweeping across the great, green lawn called a pitch), aesthetic (It was poetry), passion (the passion seen in the flags and riotous flames of countries upset), communication (Sports is one of the world's mother tongues), superiority (yesterday's hero, leader of the football world, a distant number two, the world's biggest sport, 'the best team, the best player, the best shoe', the number-one draft, the biggest star) and war (Brazil recaptured the world cup, an American... dominates golf, Japan won, victory, we are now on the front lines. We love a good fight) are all harnessed to the idea of sport as a business opportunity. The characterisation of sport as a business is fundamental, however, as is made more or less explicit: For eight years we were a distant number two in the world's biggest sport, football (this 'we' is not a football club, but a sports goods company), one thing that's truly global... despite almost universally inept management: sports (sport is not something people do for fun and exercise, it something that requires 'management'), Sports is (sic) one of our world's mother tongues. It is our business. It is a good business. This goes beyond 'Nike is a business that operates in the field of sport', to 'Sport is a business'; it is more than metaphorical, it is an actual invasion of sports discourse by business discourse.

Similarly, the parallel that is proposed between Brazil winning the world cup after being 'regarded by some as yesterday's hero', and Nike 'crossing the threshold of September $11^{\text {th' }}$ and 'beating the $\mathrm{S} \& \mathrm{P}^{8}$ by 45 points', is not in fact simply analogous - it is the same story. Knight asks why it matters that Brazil 'recaptured' the World Cup; his answer is that it matters 'because it is important to consumers' (not to football fans). The next paragraph reports massively under-predicted sales of their Korean national team jerseys and the 'Mercurial Vapor' football boot (the boot worn by Ronaldo as he scored against Turkey to take Brazil to the final,

\footnotetext{
8 S\&P is the Standard and Poor index of share prices of 500 companies in the US stock market, equivalent to the British FTSE 100 index, the Japanese Nikkei 225, or the NASDAQ index of technology share prices.
} 
and supplied to him by Nike) in Europe. The missing link (in the absence of cohesion markers) which gives coherence to this section of the text is the notion that consumers spent more on Nike sports goods at the time of the World Cup not to play more sports in, but to demonstrate their national loyalty at a time when the profile of football as a focus of global international rivalry was raised by Brazil's success. Sport is characterized through mass consumption, not mass physical activity in football playing.

The second half of the Letter is primarily devoted to locating Nike within the economic globalisation process. The treatment of globalisation is not through narrative, but through exposition in a series of existential clauses:

To be a global company ... means ... / Nike is global when ... / We are global when ... / Global is knowing when ... / It is ...

Globalisation is defined according to business criteria, amounting to more than simply doing business in many countries, but having integrated communication and knowledge systems across all offices, markets and sources, and coordinating decision-making to the extent of knowing when local decisions can be made independently of corporate headquarters. However one statement is 'We are global when the brand stands for the same things regardless of the geography involved'. It is not stated explicitly what the brand does stands for, but the value most frequently alluded to throughout the text is 'primacy' - winning, being number one, dominating, being the biggest. This discourse is welded onto business discourse, as in the following

It [to be global] is applying our greatest strength, delivering the best products for the best athletes, while keeping a close eye on expenses and gross margins.

Being global, then, means when consumers regardless of geography recognise the Nike brand as pre-eminent. Significantly no mention is made at all here of Nike's total dependence on international labour and manufacturing. On page six of the $10-\mathrm{K}$ statement we learn, however, that only $8 \%$ of Nike clothing sold in the US market is made in the US, and all clothing for the international market and all foot-ware is manufactured externally of the US by independent contractors, predominantly in Asia. 
Knight does not think that they have reached that point yet, but as futures orders outside America now exceed those within America for the first time (... a Nike moment ...), he is apparently anticipating being able to announce that they are global before too long. There then follows a series of six examples of the 'global' nature of sports. These are apparently random, but they are linked by being markets for Nike products: a Chinese NBA (American league) basketball star (Nike sells Nike and Brand Jordan basketball apparel and footwear), a Japanese-American speed skater (Bauer Nike Hockey sells ice skates and ice hockey kit), an African-Asian American golfer (Nikes golf business grew by 22\% in 2001-2), Japanese and Korean footballers (Nike sells team jerseys to fans). What we have here are not examples of a globalised sports culture, but of a non-American sportsman dominating American basketball, non-white Americans dominating speed skating and golf, and successes by Asian teams wearing Nike kit. 'Globalised sport' here means American sporting success with an international flavour. The significance of the final two example is more oblique; one refers to there being 'more than 100 golf courses in the Shenzhen area of China'. Doubtless this is not connected to the fact that $38 \%$ of Nike foot-ware is made in China (Annual Report Section 10-K, page 6) but to alert us to a message included in the Presidents' Letter: "With China now a member of the World Trade Organization, and Bejing the setting for the 2008 Olympics, the opportunities in that country are huge." The last example of 'global sports' is

the passion seen in the flags and riotous flames of countries upset... Moscow, Mexico City, Buenos Aires come immediately to mind...balanced by the joy of victory in Korea and Senegal.

In other words Nike has discovered that football arouses passions around the world, which may not be news to non-Americans, but is quite important to Nike in terms of their marketing of football kit. In both of these examples, 'global sports' is equated with international business opportunities. We can doubtless look forward to many more international 'Nike moments'. 


\subsection{Reebok}

This final analysis is included by way of contrast, to show that some companies do not consider it necessary to engage in the kind of discourse strategies discussed above. Reebok International Ltd. of Massachusetts markets sports and fitness products and casual footwear and apparel under the brands Reebok, Rockport, Ralph Lauren Footwear and Greg Norman. Whilst in the 'analysis of business environment / justification of strategy' section it describes itself as a 'global' company, the Chairman and CEO's Letter to Shareholders contains no mention of the international dimension to its operations. Nor does it attribute its products with any particular values, let alone peculiarly American values. Its 2001 Annual Report contains no vision statement, mission statement, or slogans. It is written solely in marketing and financial discourse. The sole reference to company values in the Letter is a paragraph outlining the company's 'commitment to corporate social responsibility, led by our stand for human rights' and 'unwavering respect for individual human dignity'. The annual Reebok Human Rights Award is mentioned.

Instead generating and maintaining company values and brand image discursively, Reebok promotes the brand through sponsorship 'relationships with major sports figures, teams, leagues and other organisations', in the fields of tennis, basketball, baseball, soccer, American football and running. They actively participate in youth culture marketing. While Hilfiger is resisting competitors offering 'fashion forward "street" wear' by 'remaining 'true to our design roots', Reebok are going full out for identification with the street scene. A press release date August 2002 on the Investor Relations page of the reebok.com website, for example, announces this year's Reeboksponsored promotion of an annual hip-hop talent competition in partnership with The Source - 'the number-one selling music magazine on newsstands in the U.S.' Entries have to record a rap demo including the word Reebok, or the name of a Reebok sponsored athlete or a Rbk Collection product. The winner receives Reebok-related prizes as well as the opportunity to access the rap music industry. However, none of the discourses or styles that enter into their branding strategies are present in the Annual report, which is a strictly business document. 


\section{Conclusion}

The company reports considered here have, in varying degrees, been colonised as promotional tools to market the business itself. Given the importance of branding in the sports / fashion business the kind of selfpresentation described above should not perhaps be surprising. It is possibly more surprising to find similar discourse strategies at work in fields not dependent on 'mass customisation', such as technology-based companies (Nokia, IBM), pharmaceuticals, chemicals and bio-technology (Aventis, BASF Group, Monsanto). These companies share a sensitivity to their social acceptability and a recognition that they are dependent on public approbation as much as the quality of their products. In the sports / fashion field brand image ranks alongside customer service as the major source of company value. We have seen that some of these companies do not hesitate to attach American values to their fashion values, and to project themselves as globalised American businesses. As Smith (1997) points out, this strategy serves to obscure the economic processes behind global capital and labour markets on the one hand, and the cultural processes which are subject to and contribute to on the other. In extending the global reach of their markets these companies are explicitly projecting American values, not just fashion concepts but underlying patriotic company values, into an international sphere: this is not 'globalisation' in the sense of wide-ranging international networks of inter-dependent markets and resources, it is economic and cultural colonisation. What significations are attached to these products when they enter the global market place is unpredictable, a matter not under the control of the companies themselves. Yet if Adidas can market and sell trainers 'designed to be worn without laces' to capitalise on a trend born out of resistance to company values attached to the brand, we must not underestimate the resourcefulness of these businesses. The Letters to Shareholders are as notable for their omissions as for what they say, and to the extent that they constitute a window into the thinking behind company self-representation in their Annual Reports are a valuable indicator of company ideology.

E-mail:sng5@leicester.ac.uk 


\section{REFERENCES}

Adidas-Salomon Annual Report 2002 http://www.adidas-salomon.com/ en/investor/_downloads/pdf/annual_reports/2001/AR_englisch 2001_e.pdf.

Annual Reports Library http://www.zpub.com/sf/arl.

Eggins, S., \& Slade, D. 1997. Analysing Casual Conversation. London: Cassell. Fairclough, N. 1992. Discourse and Social Change. Cambridge: Polity. . 1995a. Critical Discourse Analysis. Harlow: Longman. . 1995b. Media Discourse. London: Edward Arnold.

HABERMAS, J. 1984. The Theory of Communicative Action Vol $1:$ Reason and the Rationalisation of Society. Boston: Beacon Press.

KLeIN, N. 2000. No Logo. London: Flamingo.

McMonnies, P. N. (ed) 1988. Making Corporate Reports Valuable. London:

Kogan Page / The Institute of Chartered Accountants of Scotland.

Nike Annual Report 2002 http://www.nike.com/nikebiz/invest/reports/ ar $02 /$ index.html.

Polo Ralph Lauren Annual Report 2002 http://investor.polo.com/.

Reebok International Annual Report 2001 http://www.reebok.com/ Reebok/US/investors/Annual/2000.pdf.

Report Gallery http://www.reportgallery.com.

Ross, A. (ed) No Sweat. Fashion, free trade, and the rights of garment workers. London: Verso.

Sмith, P. 1977. Tommy Hilfiger in the age of mass customization. In: Ross, A. (ed) No Sweat. Fashion, free trade, and the rights of garment workers. London: Verso.

The Daily Enron http://www.thedailyenron.com.

Tommy Hilfiger Annual Report 2002 http:// www.hilfiger.com/info/ investor-relations.jhtml.

Van Leeuwen, T. 1987. Generic strategies in press journalism. Australian Review of Applied Linguistics, 10(2): 199-220.

. 1993. Genre and field in critical discourse analysis: a synopsis. Discourse and Society, 4(2): 193-223. 


\section{Appendix}

\section{Nike Annual Report 2002 Chairman's Letter to Shareholders}

To Our Shareholders:

I can picture them still. That wave of yellow sweeping across the great, green lawn called a pitch. As the world stood witness, Brazil recaptured the World Cup. But it was something more than victory. It was poetry.

Why does it matter?

It matters because it is important to consumers.

Fans in Korea snatched up 150,000 Nike national team jerseys, a demand that outpaced predictions by a factor of 10 . In leading retail shops across Europe, a $\$ 175$ boot we call the Mercurial Vapor led all other boot sales; this in the heart of the game's old guard. We have an operating principle at Nike that states, "The Consumer Decides." Let's just say our faith in their decisions has never been stronger.

It matters because of what Brazil proved... and proved wrong. Regarded by some to be yesterday's hero, distracted by a welter of political noise, Brazil showed its true color as leader of the football world.

We came back, too.

We entered FY '02 with a $1 \%$ decline in U.S. futures orders. We had our work cut out for us. Then came September 11, and with it a bow wave of uncertainty. Restaurants, stadiums, theme parks, malls, all thinner of crowd, showed the wan face of anxiety. We were at a threshold, one of those defining moments that pop up out of nowhere in every life, both individual and corporate. You can cross that threshold with courage or turn away in fear. Either way, you change forever.

We decided to cross the threshold of September 11. Eight months later we delivered a $14 \%$ increase in earnings, and beat the S\&P by 45 points ( $+31 \%$ vs. $-14 \%$ )... a defining moment...a Nike moment.

The World Cup mattered in other ways, too.

For eight years we were a distant number-two in the world's biggest sport, football. This year we came away from the sport's premier event with the best team, the best player, the best shoe and the best communications. We're still number-two, but we are now on the front lines. We love a good fight. And we're packing for Berlin.

Charlie Denson, who along with Mark Parker is doing such a great job as co-president of the Nike brand, says this year's football effort marked that moment when we became a real global company.

Could he be right?

Was this a Nike moment? 
To be a global company in our vocabulary means far more than to merely conduct business internationally. I have used this space before to discuss our evolutionary tale, our road to becoming global. Once a story set firmly in the future, we can now claim it to be at least a part of our present.

Nike is global when we are competently linked with all our offices, markets, and sources around the world. We are global when the brand stands for the same things regardless of the geography involved. Global is knowing when to make decisions on the ground in Shanghai or London or Rio de Janeiro, when to coordinate against approved strategy, and when to strike on instinct. It is applying our greatest strength, delivering the best products for the best athletes, while keeping a close eye on expenses and gross margins.

Many companies in our industry compete in most countries around the world, but none is really global in our definition of the word, as informed by the books of former director Ken Ohmae. Moreover, we believe that the rewards to the first company in our industry to achieve that status will be considerable.

Certainly, we have been unwavering in our goal to be that global company and have made a great deal of progress. Our management is growing into our sales.

We have for years said that growth for Nike will come from beyond America. This year, for the first time in our history, futures orders are greater outside the U.S. than inside... a Nike moment... and, we will be very disappointed if the final sales tally this time next year doesn't reflect that.

But wherever we are on that global spectrum, I'll tell you one thing that's truly global by almost any definition, and is so despite almost universally inept management: sports.

The number-one draft pick in the NBA is a 7'5" Chinese hero.

A Japanese-American speed skater was the biggest star coming out of the Salt Lake City Olympics.

An American of African-Asian descent dominates golf.

Japan won its first-ever game in the World Cup (on a goal by a Nike athlete) and Korea (wearing Nike kits) also recorded its first victory, and went on to the semifinals.

No one can doubt the passion seen in the flags and riotous flames of countries upset... Moscow, Mexico City, Buenos Aires come immediately to mind...balanced by the joy of victory in Korea and Senegal.

There are more than 100 golf courses in the Shenzhen area of China.

Sports is one of our world's mother tongues. It is our business. It is a good business. And I love being a part of it.

Nike is 30 years old this summer. We have come a long way from the days of selling shoes out of the trunk of my car. But Nike refuses to be defined by where we once stood. I consider every day of the past 30 years as preparation for this moment... this Nike moment... and all that follows. 